\title{
Lesion in the external auditory canal: an unusual site for basal cell carcinoma
}

\author{
Mikolaj Kowal, ${ }^{1,2}$ Melanie Dowling, ${ }^{1}$ Sadie Khwaja ${ }^{1}$
}

'Department of ENT, Stockport NHS Foundation Trust, Stockport, UK

${ }^{2}$ Faculty of Biology, Medicine and Health, University of Manchester, Manchester, UK

\section{Correspondence to Mikolaj Kowal, Mikolaj.kowal@student. manchester.ac.uk}

Accepted 22 November 2017

\section{DESCRIPTION}

An 85 -year-old woman presented to the ear, nose and throat clinic with a 2 -week history of left-sided otorrhoea and pruritus of the ear. Examination of the left external auditory canal (EAC) revealed a polypoidal lesion and purulent discharge (figure 1). The tympanic membrane was intact. The suspicious lesion prompted imaging, including CT neck and thorax (figure 2). An ultrasound scan of the parotid and neck showed no metastatic disease. A biopsy was undertaken and histology demonstrated a basal cell carcinoma (BCC). The patient was managed with a staged procedure. Stage 1 consisted of a wide local excision of the BCC, with a $4 \mathrm{~mm}$ margin. Frozen section was not available; therefore, a second stage was needed to achieve clear margins using a sleeve resection. Fortunately, the disease

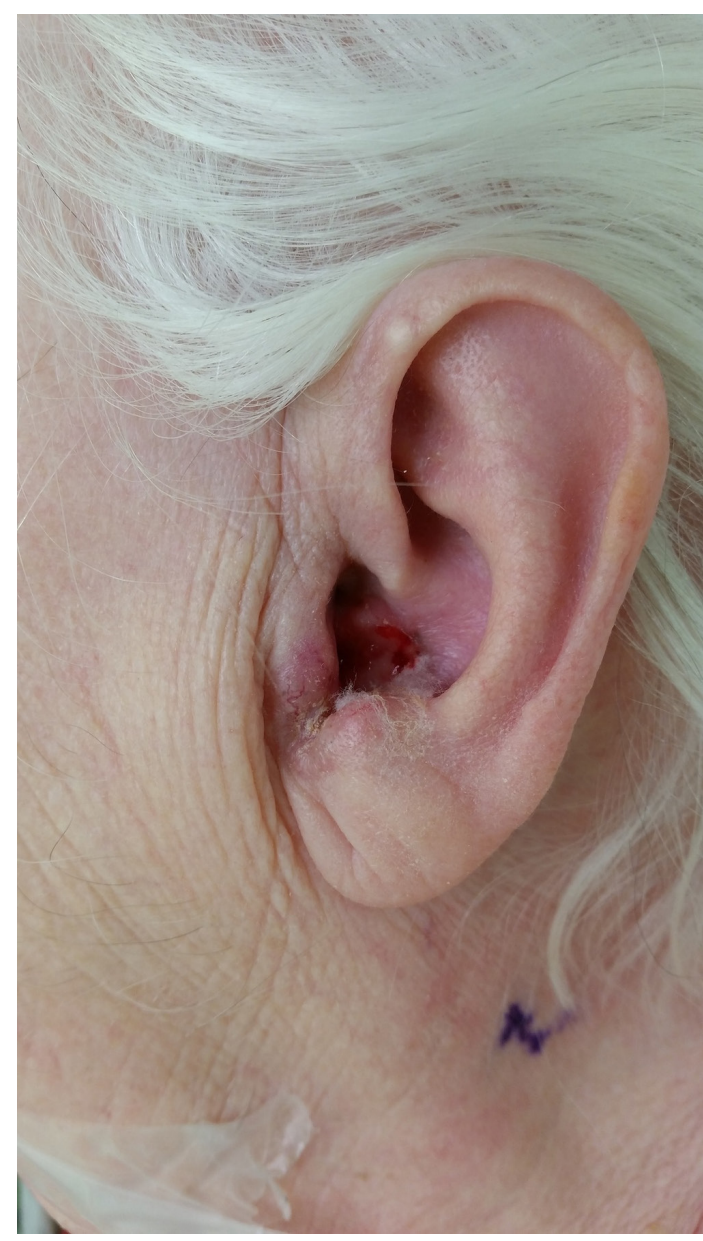

Figure 1 The innocuous appearance of a basal cell carcinoma in the external auditory canal, highlighting the difficulty in making a correct diagnosis.
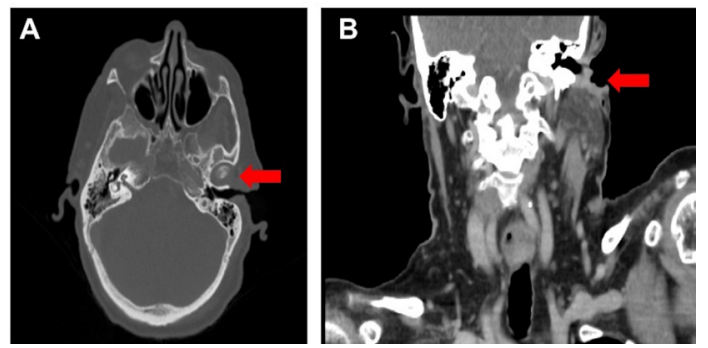

Figure 2 CT head and neck scan illustrating the cutaneous lesion involving the left pinna and external auditory canal. This shows the extent of disease and how intracranial invasion can occur in advanced disease. (A) Axial view. (B) Coronal view.

was limited to the cartilaginous ear canal, hence did not require further resection or reconstruction. This management approach was successful and the patient remains in follow-up.

The annual incidence of EAC carcinomas is around one per million. ${ }^{1}$ However, BCCs are known to be locally aggressive, which can be terminal if intracranial invasion occurs. ${ }^{2}$ Bony canal involvement may require temporal bone resection, and extensive lesions may need pinna removal and reconstruction. Early and correct diagnosis is therefore essential, specifically by healthcare professionals who frequently manage skin conditions. Out of all primary care consultations in England and Wales, 24\% are related to skin conditions according to published data. ${ }^{3}$ Greater awareness of BCCs occurring in the EAC will lead to earlier diagnosis and ultimately improve outcomes for this disease.

\section{Learning points}

Basal cell carcinomas occurring in common sites such as pinna carry a good prognosis. Basal cell carcinomas of the external auditory canal can be terminal.

- Healthcare professionals in primary and secondary healthcare should be aware of this basal cell carcinoma presentation to allow for early diagnosis and management.

- It should be explained to patients with suspected external auditory canal lesions the necessity of early treatments and surgery to avoid large defects requiring reconstruction. 
Contributors All authors participated in the work as a whole. The manuscript was written by MK, with support from MD and SK on the whole project.

Competing interests None declared.

Patient consent Obtained.

Provenance and peer review Not commissioned; externally peer reviewed.

(c) BMJ Publishing Group Ltd (unless otherwise stated in the text of the article) 2017. All rights reserved. No commercial use is permitted unless otherwise expressly granted.

\section{REFERENCES}

1 Kuhel WI, Hume CR, Selesnick SH. Cancer of the external auditory canal and temporal bone. Otolaryngol Clin North Am 1996;29:827-52.

2 Galagali JR, Ramakrishnan N, Singh R, et al. Infiltrating basal cell carcinoma with squamous differentiation: a case report. Int I Otorhinolaryngol 2016;2:40

3 Schofield J, Grindlay D, Williams H. Skin conditions in the UK: a health care needs assessment. Nottingham, UK: Centre of Evidence Based Dermatology, University of Nottingham, 2009. (accessed 26 Jun 2017).

Copyright 2017 BMJ Publishing Group. All rights reserved. For permission to reuse any of this content visit http://group.bmj.com/group/rights-licensing/permissions.

BMJ Case Report Fellows may re-use this article for personal use and teaching without any further permission.

Become a Fellow of BMJ Case Reports today and you can:

- Submit as many cases as you like

- Enjoy fast sympathetic peer review and rapid publication of accepted articles

- Access all the published articles

Re-use any of the published material for personal use and teaching without further permission

For information on Institutional Fellowships contact consortiasales@bmjgroup.com

Visit casereports.bmj.com for more articles like this and to become a Fellow 